RESEARCH ARTICLE

\title{
Diabetes in Latin America: Prevalence, Complications, and Socio- Economic Impact
}

\section{Sinisterra-Loaiza ${ }^{1}$, A Cardelle-Cobas ${ }^{1}$ AG Abraham ${ }^{2}$, MN Calderon 3 , MA Espinoza 4 , LG González- Olivares $^{5}$, M Gotteland ${ }^{6}$, A Pazos-Sierra ${ }^{7}$, S San Martin ${ }^{8}$, A Cepeda $^{1^{*}}$, JJ Gagliardino ${ }^{9}$. The IBEROBDIA Project Group}

${ }^{1}$ Departamento de Química Analítica, Nutrición y Bromatología, Laboratorio de Higiene, Inspección y Control de Alimentos, Departamento de Química Analítica, Nutrición y Bromatología, Universidade de Santiago de Compostela, Lugo, Spain

${ }^{2}$ Centro de Investigación y Desarrollo en Criotecnología de Alimentos, Argentina

${ }^{3}$ Chemistry Department, Faculty of Sciences, Universidad Nacional de Colombia, Bogotá, Colombia

${ }^{4}$ Department of Public Health, Pontificia Universidad Católica de Chile, Santiago de Chile, Chile

${ }^{5}$ Área Académica de Química, Universidad Autónoma del Estado de Hidalgo, Mexico

${ }^{6}$ Department of Nutrition, School of Medicine, Universidad de Chile, Santiago de Chile, Chile

${ }^{7}$ Department of Computer Science, Faculty of Computer Science, University of A Coruña, Spain

${ }^{8}$ Biomedical Research Center, Universidad de Valparaíso, Valparaíso, Chile

${ }^{9}$ Faculty of Medical Sciences (UNLP), CENEXA Center for Experimental and Applied Endocrinology (UNLP- CONICET La Plata), La Plata, Argentina

*Corresponding author: A Cepeda, Laboratorio de Higiene Inspección y Control de Alimentos, Facultad de Veterinaria, Pabellón 4, Planta baja, Campus Universitario Lugo, 27002-Lugo, Spain, Tel: +34-60094261, E-mail address: alberto. cepeda@usc.es

\section{Summary}

Objective: To review and update epidemiological data on type 2 diabetes (T2D) in Spain and four Latin American countries: Colombia, Mexico, Chile, and Argentina.

Methods: Literature was reviewed by a search of PubMed, publications of the Ministry of Health, World Health Organization, International Diabetes Federation, and other public health agencies of each respective country.

Results: Of the five countries above, Mexico (13.6\%) had the highest prevalence of diabetes, followed by Spain $(10.4 \%)$. Within these countries, significant differences between urban and rural areas were observed $(7.8 \%$ and $1.4 \%$, respectively). Diabetes consumes between $7 \%$ and $15 \%$ of the total expenditure of these countries' national health budgets. Mortality due to this disease has been reduced in different countries, demonstrating the success of measures taken to control this situation.
Conclusion: The literature shows that despite different eating habits and environments, Spain and these Latin American countries share a comparable magnitude of the T2D problem. Therefore, it might be worthwhile to implement similar effective educational programmes to solve it.

\section{Keywords}

Diabetes, Latin America, Prevalence, Socioeconomic impact, Complications

\begin{abstract}
Abbreviations
BP: Blood Pressure; COLCIENCIAS: The Colombia Administrative Department of Science, Technology and Innovation; CyTED: Science and Technology for Development; DM: Diabetes Mellitus; HbA1c: Glycated Haemoglobin; IBEROBDIA: Ibero-American Obesity and Diabetes program; IDF: International Diabetes Federation; IFG: Impaired Fasting Glucose; IGT: Impaired Glucose Tolerance; ISSSTE: Security ans Social Service for State Workers; NCDs: Chronic
\end{abstract}

Citation: Sinisterra-Loaiza L, Cardelle-Cobas A, Abraham AG, Calderon MN, Espinoza MA, et al. (2019) Diabetes in Latin America: Prevalence, Complications, and Socio-Economic Impact. Int J Diabetes Clin Res 6:112. doi.org/10.23937/2377-3634/1410112

Accepted: September 26, 2019: Published: September 28, 2019

Copyright: (C) 2019 Sinisterra-Loaiza L, et al. This is an open-access article distributed under the terms of the Creative Commons Attribution License, which permits unrestricted use, distribution, and reproduction in any medium, provided the original author and source are credited. 
Non-Communicable Diseases; NCD-RisC: Non-Communicable Diseases Risk Factors Collaboration; ND: Diabetic Neuropathy; NFD: Diabetic Nephropathy; OGTT: Undergone an Oral Glucose Tolerance Test; QALYs: Quality Adjusted Life Years; T2D: Type 2 Diabetes; WHO: World Health Organization

\section{Introduction}

Diabetes Mellitus (DM), one of the largest epidemics of the $21^{\text {st }}$ century [1,2], is a chronic condition due to lack or insufficient production of insulin to cope with increased demand from peripheral tissues with a resulting constant increase in blood glucose [3]. It imposes a heavy burden on both the person suffering the disease as well as the public health system.

Type 2 diabetes (T2D), is the most frequent clinical form of this disease (about 90\% of all cases) [4] that frequently appears in older adults but is currently increasing its development at younger ages -even children and adolescents- associated with a higher incidence of obesity, sedentary lifestyle, and unhealthy diets [5].

T2D usually develops asymptomatically, making early diagnosis difficult to establish, and frequently taking a decade or more to reach one [6]. It is characterized by a decrease of tissue sensitivity to insulin (insulin resistance), together with decreased mass and function of pancreatic $\beta$-cells [7]. This defect leads to impaired glucose metabolism in liver, muscle, and fat cells [8].

The development of T2D is preceded by a stage of prediabetes characterized by blood glucose concentrations above normal ( $>100 \mathrm{mg} / \mathrm{dL}$ ) but below the cut off for diabetes diagnosis ( $\geq 126 \mathrm{mg} / \mathrm{dL}$ ), which implies a higher risk of developing T2D in the future [9]. The prediabetes stage includes impaired fasting glucose (IFG), impaired glucose tolerance (IGT), and a combination of these two alterations [10]. These different stages present a different chronological degree of annual progression to T2D [6]. However, this progression is possible to prevent, and normal glucose metabolism may even be restored by the adoption of healthy life styles [11]. However, since prediabetes is frequently associated with increased risk of developing cardiovascular disease and mortality [12] as well as cancer [13], it must be considered a disease rather than a 'predisease' stage. Consequently, its early diagnosis and appropriate treatment are correspondingly important.

According to the World Health Organization (WHO), diabetes is one of the ten causes of death worldwide, a number that continues to grow. Whereas the number of deaths due to diabetes was below one million people before the year 2000, it rose to 1.6 million by 2016 [14]. Regardless of populational economic income, no country is immune to this epidemic. If the problem is not addressed in time, these rates will continue to increase.

The prevalence of diabetes shows continuous growth worldwide, and data from the Non Communicable Diseases Risk Factors Collaboration (NCD - RisC) shows that its figures have quadrupled over time $[15,16]$. For example, the International Diabetes Federation (IDF), in the eighth edition of its Atlas, estimated that in 2017 about 425 million people between the ages of 20 and 79 had diabetes [4] (Figure 1), showing continuous and alarming growth [15]. This increase has been faster in low- and middle- income countries [15].

On account of this problem, the Spain-Latin American Program of Science and Technology for Development (CYTED), has approved the IBEROBDIA study that attempts to a) Update epidemiological, metagenomic and metabolomic data on the intestinal microbiome and b) To identify new biological markers for the predi-

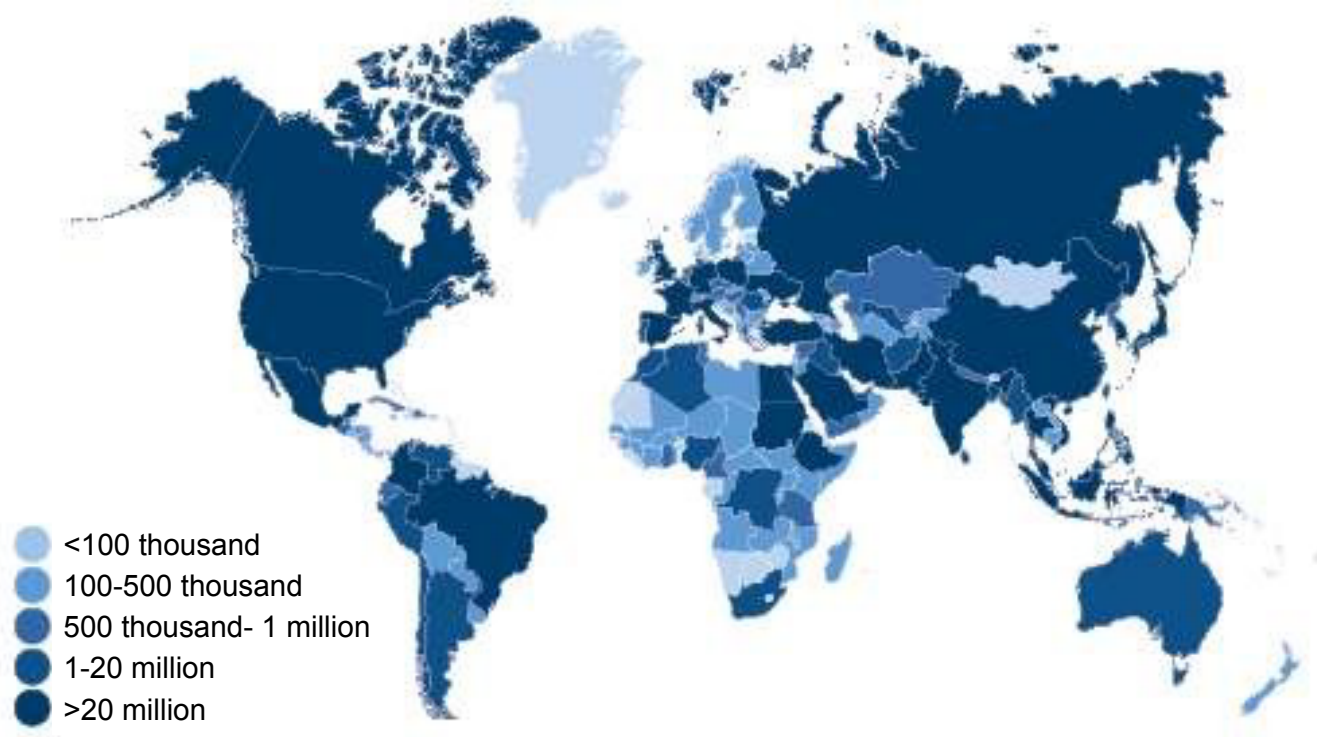

Figure 1: Estimated total number of adults living with diabetes (2017).

Source: image taken from the eighth edition of the Diabetes (IDF) Atlas [4] 
ction and early diagnosis of T2D, in Spain (Galicia) and the collaborating countries, namely, Mexico, Colombia, Chile, and Argentina. This report is related to its first step: the description of the epidemiological situation of $\mathrm{T} 2 \mathrm{D}$ in these countries.

\section{Epidemiology of T2d in Spain and Latin Ame- rica}

Chronic non-communicable diseases (NCDs) impose a heavy economic burden on the current health system; in addition, the number of people affected by NCDs is expected to increase substantially in coming decades as a reflection of global population aging and growth [17] (Table 1). The epidemiological situation in the countries involved in the IBEROBDIA programme will be described below.

\section{Spain}

In 2010 the first national study of diabetes in Spain started, aimed at providing exhaustive knowledge of T2D epidemiology (Di@betes.es); its results would be available in 2018. Preliminary data presented recently at the "Spanish Society of Obesity" Congress showed that of 2,048 patients evaluated, $85 \%$ (1,751 cases) presented an IGT, 78\% (1597 persons) had their HbA1c levels measured, and $61 \%(1,251)$ had undergone an oral glucose tolerance test (OGTT). Since 2010, 386,003 new cases of T2D have been diagnosed in Spain, approximately 44 cases per hour. This study also reflects the prevalence of diagnosed (7.8\%) and previously undiagnosed $(6 \%)$ cases of this disease $[18,19]$.

The prevalence of T2D in Spain in 2011 was known to be between $4.8 \%$ and $18.7 \%$ (8.1\%, according to the Ministry of Health and Consumer Affairs [20]), with an annual incidence of between 8.2 and 10.8 cases per 1,000 inhabitants [21]. During the period: 2010 to 2017, there was an increase of 644.9 thousand adults with some type of diabetes. Since the number of adults with this disease in 2017 was around 3.6 million, the ongoing growth of the incidence of this disease is evident $[4,22]$.

The survey performed in the last 12 months by the National Statistics Institute on chronic or long-lasting problems or illnesses in the adult population showed that the Canary Islands had the highest percentages (10.54\% and $11.66 \%$ for women and men, respectively), whereas the lowest percentages were among women in the Basque Country (4.39\%) and men in the Baleares Islands (5.20\%). In Galicia the percentages for the two sexes varied little: $8.89 \%$ and $9.49 \%$ in women and men, respectively.

\section{Latin america}

Changes in demographic and socioeconomic profiles

Table 1: Number of adults with diabetes (20 - 79 years) and national prevalence (\%) of diabetes in Spain, Portugal, and Latin American countries (2013-2017) [4].

\begin{tabular}{|c|c|c|c|c|c|c|}
\hline \multirow[t]{2}{*}{ Country } & \multicolumn{6}{|c|}{ Year } \\
\hline & 2013 & Prevalence (\%) & 2015 & Prevalence (\%) & 2017 & Prevalence (\%) \\
\hline Brazil & $11,933.6$ & 9.04 & $14,250.8$ & 10.2 & $12,465.8$ & 8.7 \\
\hline Mexico & $8,723.4$ & 11.77 & $11,463.8$ & 14.7 & $12,030.1$ & 13.6 \\
\hline Spain & $3,790.7$ & 10.83 & $3,576.1$ & 10.4 & $3,584.5$ & 10.4 \\
\hline Colombia & $2,135.4$ & 7.12 & $3,048.7$ & 9.6 & $2,671.4$ & 8.1 \\
\hline Argentina & $1,607.8$ & 5.98 & $1,723.9$ & 6.2 & $1,757.5$ & 6.2 \\
\hline Venezuela & $1,232.0$ & 6.61 & $2,133.4$ & 11.1 & $1,311.4$ & 6.6 \\
\hline Chile & $1,253.9$ & 10.36 & $1,372.7$ & 11.0 & $1,199.8$ & 9.3 \\
\hline Peru & 786.2 & 4.28 & $1,231.2$ & 6.4 & $1,130.8$ & 5.6 \\
\hline Portugal & $1,031.8$ & 12.96 & $1,049.8$ & 13.6 & $1,065.0$ & 13.9 \\
\hline Cuba & 814.5 & 9.74 & $1,020.0$ & 12.1 & 897.6 & 10.6 \\
\hline Guatemala & 661.0 & 8.97 & 761.5 & 9.1 & 752.7 & 8.4 \\
\hline Ecuador & 530.1 & 5.68 & 830.1 & 8.5 & 554.5 & 5.5 \\
\hline Dominican Republic & 652.9 & 10.66 & 505.7 & 8.1 & 520.8 & 8.1 \\
\hline Puerto Rico & 393.5 & 15.4 & 365.1 & 14.2 & 400.6 & 15.4 \\
\hline Bolivia & 361.0 & 6.29 & 389.0 & 6.5 & 391.0 & 6.2 \\
\hline Nicaragua & 344.3 & 10.25 & 275.9 & 7.7 & 373.4 & 10.0 \\
\hline El Salvador & 338.8 & 9.42 & 325.9 & 8.8 & 332.7 & 8.7 \\
\hline Costa Rica & 218.8 & 6.78 & 278.9 & 8.6 & 319.1 & 9.5 \\
\hline Honduras & 268.8 & 6.28 & 334.5 & 7.4 & 285.8 & 6.0 \\
\hline Paraguay & 236.8 & 6.17 & 324.1 & 8.4 & 298.0 & 7.4 \\
\hline Panama & 186.3 & 7.87 & 230.6 & 9.4 & 215.9 & 8.5 \\
\hline Uruguay & 143.8 & 6.34 & 157.6 & 6.9 & 152.8 & 6.6 \\
\hline
\end{tabular}


in this region have induced important changes in its epidemiological profiles.

However, large differences have been found within countries when urban and rural settings were compared. For example, the Colombian population showed a five-fold difference between urban (7.8\%) and rural (1.4\%) populations [23]. The data suggest that these differences could be attributed to changes in the lifestyle and diet of modern society. Therefore, actions aimed against these changes might provide a challenging opportunity to develop primary prevention strategies [24].

Mexico: Mexico is the main consumer of sugary drinks and is also the country with the largest obese population in the world: the combined prevalence of obesity and overweight in adults is $71.3 \%[25,26]$.

In 2012 diabetes prevalence was 9.2\%, which means that 12 million people 20 years and older have diabetes. Of this diagnosed population just over $80 \%$ receive treatment. However, only $25 \%$ attained treatment targets, and therefore, $24.7 \%$ are at moderate risk while $49.8 \%$ are at very high risk of developing complications [27]. For this reason the disease became the main cause of demand for outpatient medical care, causes of hospitalization, of blindness, chronic renal insufficiency and non-traumatic amputations. It is also the main cause of death in adults $55-74$ years old, and its control/treatment consumes $2.4 \%$ of the Gross Domestic Product [28].

It was predicted that by 2050 diabetes prevalence could reach between $14 \%$ and $22 \%$. The high prevalence of obesity in this country, which accounts for $17.5 \%$ of the male and $25.2 \%$ of the female population could explain, at least partly, this predicted increase [29].

In 2008, the Staged Diabetes Management Program "MIDE" at the Institute for Security and Social Services for State Workers (ISSSTE) changed the paradigm of diabetes care in Mexico: it was the first institution with $\mathrm{HbA} 1 \mathrm{c}$ as the glycemic monitoring test, setting a precedent that would revolutionize diabetes care in the country. The MIDE Program, launched in 2014, has contributed to the integration of the National Strategy for Prevention and Control of people with overweight/ obesity and diabetes. In the MIDE program, $100 \%$ of the patients are monitored with $\mathrm{HbA} 1 \mathrm{c}$ and $62 \%$ of them achieved treatment target values.

Colombia: Colombia is the third largest country in Latin America with approximately 48 million inhabitants. The prevalence of T2D in the adult population (over 20 years of age) is between 7 and $9 \%$, but is 5 times lower in the rural population, resulting in around 2 million people with the disease; this fact represents a challenge for the future, especially for the identification and treatment of those who are unaware of their diagnosis [30].
The CARMELA study reported that 1,553 people (average age 47.5 years) living in the capital city (Bogotá) had a prevalence of T2D of $8.1 \%$ (7.4\% in women and $8.7 \%$ in men) [31].

In 2005, the self-reported prevalence of diabetes diagnosis in adults (18 to 64 years of age) showed a higher prevalence in people between 50 and 64-years-old, in male adults, as well as in those with no formal education and in those who had low income [32]. Although no reliable information exists on the rate of the rise in diabetes prevalence, considering the relationship between diabetes and obesity, it may be assumed to increase in parallel with the degree of adiposity. Comparing data from the two ENSIN surveys (2005 and 2010) of people between 18 and 64 years of age, the prevalence of overweight/obesity increased by $5.1 \%$ : overweight and obesity separately increased by $2.3 \%$ and $2.8 \%$, respectively, over a 5-year period [33].

The national healthcare system is leveraged by two large entities: the Subsidized and the Contributive system. The former includes low income patients that have a government-subsidized healthcare plan, whereas the contributive system includes employees from whose salaries a $12.5 \%$ monthly discount is subtracted (as established by law); it is called POS based on its acronym in Spanish [34].

Fasting blood glucose measurement is included for diagnosis (mandatory for people over 40 years of age), OGTT and glycated haemoglobin (HbA1c). The POS does not include 24-hour blood glucose monitoring, but it may be requested through the Technical-Scientific Committee.

Since T2D is one of the 5 leading causes of death and one of the main 10 causes of medical consultations in the adult population in Colombia, the Colombian Administrative Department of Science, Technology and Innovation (COLCIENCIAS) have requested that the Health Technology Assessment Institute and the Pontificia Universidad Javeriana, draft a clinical practice guideline for the diagnosis, treatment, and follow-up of T2D in the population over 18 years of age [35]. Although this guideline was not published in a scientific journal, it has been available locally since March 2016. Its main objective initially was to identify people with undiagnosed diabetes that could benefit from early diagnosis/treatment [30].

This guideline provides diagnostic values for the screening and diagnosis of T2D, as well as values to identify people at risk of developing diabetes. In all cases it recommends diabetes education (adoption of a healthy lifestyle) emphasizing the importance of appropriate glycemia control to reduce T2D risks factors identified by the FINDRISC questionnaire [36]. The use of HbA1c is suggested as a strategy for T2D diagnosis in patients with fasting blood glucose 
between 100 and $125 \mathrm{mg} / \mathrm{dl}$ [37]. The use of OGTT is recommended for T2D diagnosis in patients with fasting plasma blood glucose between 100 and 125 $\mathrm{mg} / \mathrm{dL}$ [38].

Chile: According to available national representative surveys taken in Chile in 2003, 2010, and 20162017 , the prevalence of diabetes in the population over 15 years of age was $6.3 \%, 9.4 \%$ and $12.3 \%$, respectively $[39,40]$. Data indicate a continuous growth of such prevalence that 1.8 million people are affected with this condition, of which approximately $90 \%$ suffer T2D. Further, the annual growth of prevalence has been projected by a stock and flow mathematical model using trends provided by the three NHSs: population growth, mortality rates, and obesity rates. Assuming a linear growth trend and the same average growth rate as in the previous 17 years, the prevalence by 2035 is expected to be $19.6 \%$ [41].

On the other hand, the Ministry of Health made the last study of burden of disease (BOD) in Chile in 2008. At that time, diabetes was located in the tenth place of specific causes based on Disability Adjusted Life Years (DALYs). Diabetes accounted for 72,230 DALYs, which corresponds to approximately $2 \%$ of this country's total BOD [42].

Regarding access to healthcare, of the $78.5 \%$ of people diagnosed with diabetes, only $58.5 \%$ received treatment and $34 \%$ achieved treatment goals ( $\mathrm{HbA} 1 \mathrm{c}$ $<7.0 \%)[43,44]$. The impact of this low effective coverage/metabolic control was studied using the IMS Core Model for Chile. Interestingly, it was reported that if $50 \%$ of diabetic patients could achieve the glycemic goals (and 20\% reach those for blood pressure and dyslipidemia), the country would avoid 13,983 cases of blindness, 12,539 cases of acute myocardial infarction and 22,464 deaths in a 10 year period [45]. A complementary analysis used individual risk profiles of diabetic patients provided by the NHS 2010 in the context discrete event simulation model to project outcomes based on the UKPDS Outcome Model 2 [46]. From this analysis it was estimated that a newly diagnosed diabetic patient who did not suffer any complication during his/her life would live on average 17.08 Quality Adjusted Life Years (QALYs). If complications such as heart failure or end-stage renal disease would occur, expected QALYs would decrease to 14.85 or 11.31 , respectively.

In terms of economic costs, the International Diabetes Federation estimated that $10.2 \%$ of the total health expenditure was attributable to diabetes in 2013 [47]. This is equivalent to USD \$1,427 per diabetic person per year [45]. It was also estimated that a newly diagnosed patient with no complications during his/her life would cost USD $\$ 12,300$, on average, an amount that would increase to USD $\$ 16,500$ if heart disease appeared and
USD \$99,500 if end-stage renal disease were diagnosed [41].

All together, these figures support the concept that prevention of the development/progression of diabetes complications by attaining treatment goals, is a cost-effective approach to optimize the use of resources.

Argentina: Diabetes prevalence in the country rose from $8.4 \%$ to $9.8 \%$ in the $2005-2013$ period, and was higher in the elderly, women with obesity, and people with lower income and low educational level [48]. Also, the number of undiagnosed and untreated people is high. Despite the knowledge that tight control of hyperglycemia and associated cardiovascular risk factors effectively prevents the development of chronic complications, most people with diabetes do not achieve appropriate treatment goals to reach this prevention [49].

This in turn results in decreased quality of life of these people and in a higher cost of care. In this regard, diabetic retinopathy is the number one cause of non-traumatic blindness; diabetes is also the leading cause of dialysis, accounting for $34.7 \%$ of incidental cases and $22.8 \%$ of renal failures [50,51]. However, the leading cause of death in people with diabetes is cardiovascular disease.

Diabetes prevalence in Argentina, compared to other countries in the region, is higher than in Uruguay and in many Brazilian cities (where it is between 3.6 and 6.9\%).

It has been shown that education of healthcare providers and people with diabetes can effectively change this situation, especially by implementing these programs at the primary care level and establishing coordinated activity between the different levels of care. Several examples of local evidence support this assumption, such as the PROPAT project developed by IOMA (social security organization of the Province of Buenos Aires [52]. The PRODIACOR program in the Province of Corrientes [53], and, most recently, DIAPREM in the Municipality of La Matanza, Province of Buenos Aires [54], also improved the quality of care provided to people with T2D. In all of these programs, the diabetes education given and the organization of care promoted a significant improvement in clinical and metabolic indicators, and also reduced care costs. DIAPREM provided education, but also added the systematic recording of variables (QUALIDIAB), the setting-up of a call center, and medical consultations scheduled with a cardiologist and an ophthalmologist. The education program was devoted to doctors in an online format whereas the program for nurses was given face to face in the intervention group. In the control group physicians and nurses continued to work as usual.

At the DIAPREM program startup, patients in both groups showed indicators of similarly poor quality of care (low percentage of patients with values for 
Body Mass Index (BMI), HbA1c, blood pressure, and target lipid profile). However, these indicators improved significantly after 6 months in the intervention group, and continued to improve after 12 months of follow-up. Conversely, no significant improvement in any of these parameters was recorded in the control group. These results demonstrate that diabetes education implemented at all three levels improves the quality of care and quality of life of people with diabetes, also reducing the cost of their care.

\section{Comorbidity}

When diabetes is poorly controlled - particularly when this deficient control continues for long periods - facilitates the development of a number of complications and comorbidities, as well as at least doubling the risk of death due to heart disease and stroke [47].

Diabetes complications can affect small and large vessels, promoting micro- and macroangiopathy: whereas the former is diabetes specific and is responsible for most disabilities, the latter is frequently associated with other cardiovascular risk factors. However, it is 2 to 4 times greater in people with T2D than in their non-diabetic counterparts, which thereby makes it responsible for the main causes of death in adults worldwide [55].

Microangiopathic complications include:

- Diabetic Retinopathy (DR) is the main cause of non-traumatic blindness in adults; its prevalence in Europe has been estimated at 3-4\%. However, the situation of patients with TD2 must be differentiated, since the prevalence increases to $60 \%$ for them [56].

In Mexico in 2012, 47.6\% of patients with diabetes reported impaired vision, $13.9 \%$ had damage to the retina and $6.6 \%$ had total loss of sight [28].

In Chile DR is the main cause of blindness. A study of diabetic subjects lasting over 5 years showed that $48 \%$ had retinopathy and $25 \%$ had advanced retinopathy [40].

- Diabetic nephropathy (NFD), if not detected and treated at an early stage, NFD may progress to chronic renal failure. Diabetes is one of the leading causes of renal failure, with approximately $10 \%$ to $20 \%$ of patients with diabetes dying from this cause [57]. In Chile, $35 \%$ of all cases of advanced chronic renal failure are known to be related to diabetes. Chile is the country with the highest frequency of renal replacement therapy in South America [40].

- Factors such as low blood pressure (BP) and appropriate glycemic control may decrease its incidence in the diabetic population [58].

Although this complication is not as frequent, according to data from the National Health and Nutrition Survey (ENSANUT) in Mexico, by 2012 1.4\% of patients with diabetes were on peritoneal dialysis.
Despite the low percentage, this treatment constitutes a considerable economic burden in health expenditures [57].

- Diabetic Neuropathy (ND) is the third chronic complication of diabetes. Although it is the most common (its estimated prevalence exceeds $50 \%$ ), it is also the least studied, as its diagnosis is difficult and its pharmacological treatment is limited [59].

- Five percent of patients present neuropathy symptoms within five years of diagnosis and $50 \%$ within twenty-five years. Drug use, such as alcohol and tobacco, and the presence of peripheral vascular disease favours its development [59].

\section{Mortality}

Spain is one of the countries within the European Union where T2D has the greatest impact on both the population and the health care system, accounting for $2.4 \%$ of all deaths with a mortality rate in 2015 of 22 per 100,000 [60]. In men it represents $2 \%$ of all deaths having a mortality rate of 19.4 per 100,000 inhabitants, while in women it was responsible for $2.8 \%$ of deaths with a mortality rate of 24 per 100,000 inhabitants. In Latin America, non-communicable diseases: diabetes, cancer, respiratory diseases, and cardiovascular diseases, are the four main causes of death. Between 2010 and 2013 , diabetes was the second leading cause of death in the 25-64 age group with 19.1 per 100,000 inhabitants [61]. In 2014, the age-standardized mortality rate for T2D in the region shows a slight difference between men $(35.6 \%)$ and women (31.6\%) per 100,000 inhabitants.

In Mexico, since 2000, T2D ranked in the first position since accounted for $14.8 \%$ of deaths recorded in 2014 [62]. The mortality rate per 100,000 inhabitants was more than twice that in Brazil, more than three times the rate in Chile and 14 times the rate recorded in the United Kingdom [58].

From 2015 to 2017, diabetes mortality in the region has decreased, from 247,500 to 209,717 deaths, respectively. In 2017 , about $44.9 \%$ of all these deaths occur in people under 60 years of age.

The reduction in mortality by some countries indicates that control of diabetes is possible to a significant degree. Despite the reduction in deaths without any adjustment for population growth, it indicates that measures have been taken to control this condition.

On account of this situation some countries have implemented programs to combat, prevent, and improve quality of care in order to ameliorate this situation. In Spain and the different countries of Latin America a reduction in mortality has been observed, namely: in Spain it decreased by $34.6 \%$ [63], in Colombia by $31.3 \%$ [64], in Argentina by $29.3 \%$ [65,66], and in Chile by $7.6 \%$ [67]. 


\section{Health Care Costs Associated with T2D}

Diabetes in adults is a growing health burden. The IDF has estimated that in 2017 the total healthcare expenditure on diabetes care will reach US\$ 727 billion, an increase of $8 \%$ compared to 2015 estimates. This economic burden of diabetes will continue to increase, with healthcare expenditures expected to reach US\$ 776 billion by 2045 , which represents a $7 \%$ increase [4].

Diabetes in Spain is the main chronic disease and its direct costs represent $7 \%$ and $13 \%$ of the total expenditure of the National Health System [68].

In 2014, Chile spent $\$ 21.2$ billion on health care, of which $10.2 \%$ were invested in people with diabetes, which means an average of US\$1,427 per person with diabetes per year [69].

In 2013, diabetes health care costs amounted to 6.53 million dollars $(5,809$ million euros), representing $8.2 \%$ of the total health care expenditure [70]; $38 \%$ of the total cost was spent on drug treatments, followed by hospital costs (33\%) ascribed to events related to diabetes complications events [71].

A review of 89 papers published by the Spanish Ministry of Economy and Competitiveness for the period 2000-2014 on the average total cost of a person with diabetes (at an international and national level, Europe and the United States of America) indicated that this cost fluctuated between $\$ 1,251.67$ (1€ = 1.13 US dollars, February 2019) and $€ 7,080.74$ per year (a ratio of 5.7). The variability in the magnitude of the average direct healthcare cost is also around 5, fluctuating between $\$ 776.08$ and $\$ 4,115.37$ per patient per year [68].

\section{Conclusions}

According to this brief literature review on data from Spain and some Latin American countries included in IBEROBDIA programme (Mexico, Colombia, Chile, and Argentina), it can be concluded that:

- The high levels of obesity frequently associated with prediabetes present in the population increase the risk of developing T2D. If this trend continues to increase, in the relatively near future the percentage of people with diabetes will reach $50 \%$ of the population.

- In both Spain and Latin American countries included in this review, the problem is quite similar despite apparently different lifestyle habits and environment.

- On the other hand, consistent data from the literature has confirmed that promotion of the adoption of a healthy life style through structured diabetes education programs is very effective in delaying the transition from prediabetes to $T 2 D$ in risk populations and also in improving T2D control.
In view of these data, it is obviously necessary to promote the active implementation of diabetes education strategies to obtain an effective and sustainable decrease of the current socioeconomic diabetes burden.

Complementarily, studies such as the IBEROBDIA that will provide new key results on the epidemiology and pathogenesis of the disease could help to achieve this aim by facilitating the development of an interdisciplinary and intersectoral approach.

\section{Declaration of Potential Conflicts of Interest}

The authors declare that there is no conflict of interest in relation to the content of this article.

\section{Acknowledgement}

The authors thank the CYTED and each National Organism for Science and Technology for funding the IBEROBDIA project (P918PTE0409). In this regard, Spain specifically thanks the Ministry of Economy and Competitiveness for the financial support for this project through the State Program of $1+D+1$ Oriented to the Challenges of Society 2017-2020 (International Joint Programming 2018). Projects PCI2018-093245 and PCl2018-093284. Argentina thanks ministry of Science, Technology and Productive Innovation of Argentina for the financial contribution to this Project. Mexico thanks to National Council for Science and Technology (CONACYT) for the management of the resources granted by CYTED. Chile thanks to CONICYT, Project on Strategic Issues CYTED-CONICYT, Convocation 2017, 918PTE0540 and Colombia thanks COLCIENCIAS for the grant 8732017. Also, thanks to Mrs. Susan Hale Rogers for careful manuscript edition/correction.

\section{References}

1. Zimmet PZ (2017) Diabetes and its drivers: The largest epidemic in human history? Clinical Diabetes Endocrinology 3: 1-8.

2. Awad SF, O'Flaherty M, Critchley J, Abu-Raddad LJ (2018) Forecasting the burden of type 2 diabetes mellitus in Qatar to 2050: A novel modeling approach. Diabetes Res Clin Pract 137: 100-108.

3. Kharroubi AT, Darwish HM (2015) Diabetes mellitus: The epidemic of the century. World J Diabetes 6: 850-867.

4. International Diabetes Federation. IDF Diabetes Atlas, 8th edn. Brussels, Belgium: International Diabetes Federation, 2017.

5. Ruiz-Ramos M, Escolar-Pujolar A, Mayoral-Sánchez E, Corral-San Laureano F, Fernández-Fernández I (2006) La diabetes mellitus enEspaña: Mortalidad, prevalencia, incidencia, costes económicosy desigualdades. Gaceta Sanitaria 20: 15-24.

6. Serrano Martín R (2017) Prediabetes. In: Tratado de Diabetes Mellitus. ( $2^{\text {nd }}$ edn), Panamericana, Madrid, España.

7. Olokoba AB, Obateru OA, Olokoba LB (2012) Type 2 diabetes mellitus: A review of current trends. Oman Med J 27: 269-273. 
8. Gutiérrez-Rodelo C, Roura-Guiberna A, Oliveres-Reyes JA (2017) Mecanismos moleculares de la resistencia a la insulina: Una actualización. Gac Méd Méx 153: 214-228.

9. Serrano Martín R (2015) ¿Cuáles son los criterios de prediabetes? In: Guía actualizada en diabetes mellitus tipo 2. Fundacion redGDPS, Badalona.

10. Mata-Cases M, Artola S, Escalada J, Ezkurra-Loyola P, Ferrer-García JC, et al. (2015) Consenso sobre la detección y el manejo de la prediabetes. Grupo de Trabajo de Consensos y Guías Clínicas de la Sociedad Española de Diabetes. Atención Primaria 47: 456-468.

11. Hernández Ruis de Eguilaz M, Betle MA, Martínez de Morentin B, San-Cristóbal R, PéreZ-Diez S, et al. (2016) Alimentary and lifestyle changes as a strategy in the prevention of metabolic syndrome and diabetes mellitus type 2: Milestones and perspectives. An Sist Sanit Navar 39: 269-289.

12. Huang $Y$, Cai X, Chen $P$, Mai W, Tang H (2014) Associations of prediabetes with all-cause and cardiovascular mortality: A meta-analysis. Ann Med 46: 684-692.

13. Huang Y, Cai X, Qiu M, Chen P, Tang H, et al. (2014) Prediabetes and the risk of cancer: A meta-analysis. Diabetologia 57: 2261-2269.

14. World Health Organization (2018) The top 10 causes of death.

15. Mendoza Romo MA, Padrón Salas A, Cossio Torres PE, Soria Orozco M (2017) Prevalencia mundial de la diabetes mellitus tipo 2 y su relación con el índice de desarrollo humano. Rev Panam Salud Publica 41: e103.

16. NCD Risk Factor Collaboration (2016) Worldwide trends in diabetes since 1980: A pooled analysis of 751 population-based studies with 4.4 million participants. The Lancet 387: 1513-1530.

17. Bloom DE, Cofiero ET, Jane-Llopis E, Abrahams-Gesse S, Bloom LR, et al. (2011) The global economic burden of noncommunicable diseases. World Economic Forum and the Harvard School of Public Health, Switzerland.

18. Pinilla J, Barber P, González-Valcárcel B (2017) El coste de la enfermedad potencialmente prevenible en España. Fundación MAPFRE, Madrid.

19. Soriguer F, Goday A, Bosch-Comas A, Bordiú E, CAlle-Pascual A, et al. (2012) Prevalence of diabetes mellitus and impaired glucose regulation in Spain. Diabetologia 55: 8893.

20. Estudio Di@bet.es (2011) Prevalencia de la diabetes en España. Dossier de prensa.

21. Valdes S, Botas P, Delgado E, Alvarez F, Cadorniga FD (2007) Population-based incidence of type 2 diabetes in northern Spain: The Asturias Study. Diabetes Care 30: 2258-2263.

22. International Diabetes Federation (2011).IDF Diabetes Atlas, $5^{\text {th }}$ edn. Brussels, Belgium:International Diabetes Federation.

23. Aschner P, Aguilar-Salinas C, Aguirre L, Franco L, Gagliardino JJ, et al. (2014) Diabetes in South and Central America: An update. Diabetes Res Clin Pract 103: 238-243.

24. Aschner P (2010) Epidemiología de la diabetes en Colombia. Av en Diabetol 26: 95-100.

25. Meza R, Barrientos-Gutierrez T, Rojas-Martinez R, Reynoso-Noverón N, Palacio-Mejia LS, et al. (2015) Burden of type 2 diabetes in Mexico: Past, current and future preva- lence and incidence rates. Prev Med 81: 445-450.

26. Salas-Zapata L, Palacio-Mejía LS, Aracena-Genao B, Hernández-Ávila JE, Nieto-López E (2016) Costos directos de las hospitalizaciones por diabetes mellitus en el Instituto Mexicano del Seguro Social. Gac Sanit 32: 203-318.

27. Jiménez Corona A, Rojas Martínez R, Villalpando S, Barquera S, Aguilar Salinas C (2012) Diabetes mellitus: La urgente necesidad de reforzar la respuesta en políticas públicas para su prevención y control. Encuesta Nacional de Salud y Nutrición, México, 1-200.

28. Programa de manejo integral de diabetes por etapas. Mide. Lineamientos. México.

29. Vargas-Uricoechea H, Casas-Figueroa LÁ (2016) Epidemiología de la diabetes mellitus en Sudamérica: La experiencia de Colombia. Clin Investig Arter 28: 245-256.

30. Vargas-Uricoechea H, Casas-Figueroa LÁ (2015) An epidemiologic analysis of diabetes in Colombia. Ann Glob Health 81: 742-753.

31. Schargrodsky $H$, Hernández-Hernández R, Champagne BM, Silva H, Vinueza R, et al. (2008) CARMELA: Assessment of cardiovascular risk in seven Latin American cities. Am J Med 121: 58-65.

32. Instituto Colombiano de Bienestar Familiar (2006) Encuesta nacional de la situación nutricional en Colombia. Panamericana Formas e Impresos, S.A. Bogotá.

33. Herrán OF, Patiño GA, DelCastillo SE (2015) Desigualdad y nutrición: Encuesta de la situación nutricional en Colombia, 2010. Rev Bras Saude Mater Infant 15: 401-412.

34. Ministerio de Salud Colombiano (2019) Plan obligatorio de salud POS.

35. (2016) Clinical practice guide - For the diagnosis, treatment and follow up of type 2 diabetes mellitus in population over 18 years old. General Social Security Health System. Ministerio de Salud y Protección Social Departamento Administrativo de Ciencia, Tecnología e Innovación - Colciencias, Colombia.

36. Lindström J, Tuomilehto J (2003) The diabetes risk score: A practical tool to predict type2 diabetes risk. Diabetes Care 26: 725-731.

37. David M Nathan (2009) International expert committee report on the role of the A1C assay in the diagnosis of diabetes. Diabetes Care 32: 1327-1334.

38. World Health Organization (2016) WHO diabetes country profiles 2016.

39. Ministerio de Salud (2018) Encuesta Nacional de Salud 2016-2017.

40. Sapunar J (2016) Epidemiología de la diabetes mellitus en Chile. Rev Med Clin Condes 27: 146-151.

41. Rojas R, Vargas C, Balmaceda C, Espinoza MA (2017) Prediction of long term outcomes of type 2 diabetes in Chile an population from the perspective of public health system. Value in Health 20: A168-A169.

42. MINSAL (2008) Estudio de carga de enfermedad y carga atribuible. Ministeriode Salud de Chile (Ejecutado por el Departamento de Salud Pública-Pontificia Universidad Católica de Chile), Santiago de Chile.

43. Aguilera X, Castillo-Laborde C, Ferrari MN, Delgado I, Ibanez C (2014) Monitoring and evaluating progress towards universal health coverage in Chile. PLoS Med 11: e1001676. 
44. MINSAL (2011) Metas 2011-2020: Ministerio de Salud de Chile. Santiago de Chile.

45. Aguero M, Allel N, Andersen J, Angles C, Aylwin CG, et al (2019) Consenso Chileno enEconomía de la Salud, Políticas Públicas y Accesoen Diabetes - Alianza por un Chile sin diabetes,Visión 2020. Rev ALAD, en prensa.

46. Hayes AJ, Leal J, Gray AM, Holman RR, Clarke PM (2013) UKPDS outcomes model 2: A new version of a model to simulate lifetime health outcomes of patients with type 2 diabetes mellitus using data from the 30 year United Kingdom Prospective Diabetes Study: UKPDS82. Diabetologia 56: 1925-1933.

47. International Diabetes Federation (2013).IDF Diabetes Atlas, $6^{\text {th }}$ edn. Brussels, Belgium: International Diabetes Federation.

48. Gonzalez L, Caporale JE, Elgart JF, Gagliardino JJ (2014) The burden of diabetes in Argentina. Glob J Health Sci 7: 124-133.

49. Elgart JF, Asteazarán S, De La Fuente JL, Camillucci C, Brown JB, et al. (2014) Direct and indirect costs associated to type 2 diabetes and its complications measured in a social security institution of Argentina. Int J Public Health 59: 851-857.

50. Vilariño JO, González CD, Grancelli H, Damiano M, Frechtel G, et al. (2014) Aumento de la prevalencia de diabetes tipo 2 y obesidaden la zona central de Argentina (1997-2010): Un estudio multietápico sistemático demográfico. Rev ALAD, Estudio Venado Tuerto 2 (VT 2), 4: 140-147.

51. Gagliardino JJ, Olivera E, Etchegoyen GS, Guidi ML, Caporale JE, et al. (2006) PROPAT: A study to improve the quality and reduce the cost of diabetes care. Diabetes Res Clin Pract 72: 284-291.

52. Prestes M, Gayarre MA, Elgart JF, Gonzalez L, Rucci E, et al. (2017) Multistrategic approach to improve quality of care of people with diabetes at the primary care level: Study design and baseline data. Prim Care Diabetes. 11: 193-200.

53. Gagliardino JJ, Lapertosa S, Pfirter G, Villagra M, Caporale JE, et al. (2013) Clinical, metabolic and psychological outcomes and treatment costs of a prospective randomized trial based on different educational strategies to improve diabetes care (PRODIACOR). Diabet Med 30: 1102-1111.

54. Prestes M, Gayarre MA, Elgart JF, Gonzalez L, Rucci E, et al. (2017) Improving diabetes care at primary care level with a multistrategic approach: Results of the DIAPREM programme. Acta Diabetol 54: 853-861.

55. Isea J, Viloria JL, Ponte Cl, Gómez M (2012) Complicaciones macrovasculares de la diabetes mellitus: cardiacas, vásculocerebrales y enfermedad arterial periférica. Revista venezolana de endocrinología y metabolismo. 10: 96-110.

56. Civera A, Figueras A, Roca M (2017) Retinopatía y otrascomplicacionesoculares de ladiabetes. Trarado de Diabetes Mellitus. ( $2^{\text {nd }}$ edn), Barcelona, Panamericana.

57. Sapunar Z J (2016) Chilean epidemiology in diabetes mellitus. Rev Med Clin Condes 27: 146-151.
58. Arredondo López AA, Barquera Cervera S, Cisneros González N, Ascencio Montiel AJ, Encarnación Cruz LM, et al. (2016) Asumiendo el Control de la Diabetes, México 2016. Fundaciones Midete, Ciudad de México.

59. Pablos Veslaco PL (2017) Nefropatía diabética. In: Tratado de diabetes mellitus. ( $2^{\text {nd }}$ edn), Panamericana, Barcelona.

60. López-Alba A, Amorín Díaz M (2017) Indicadores de Salud 2017: Evolución de los indicadores del estado de salud en España y su magnitude en el contexto de la Unión Europea. Madrid, 1-355.

61. Organización Panamericana de la Salud/Organización Mundial de la Salud, Departamento de Evidencia e Inteligencia para la Acciónen Salud/Unidad de Análisis de Salud, Métricas y Evidencia (2018) Base de Datos PLISA. Situación de Saluden las Américas: Indicadores Básicos 2018. Washington, D.C., USA.

62. Soto-Estrada G, Moreno-Altamirano L, Pahua Díaz D (2016) Epidemiological overview of Mexico's leading causes of morbidity and mortality. Rev Fac Med UNAM 59: 8-22.

63. Ministerio de Sanidad, Servicios Social e Igualdad, Gobierno de España (2012) Estrategia en Diabetes del Sistema Nacional de Salud - Actualización. MSSSI, Madrid, España 51.

64. Organización Panamericana de la Salud, OMS (2009) Recopilación de normas de prevención y control de enfermedades crónicas en América Latina: Obesidad, Diabetes y Enfermedades Cardiovasculares. Washington DC, USA.

65. Ministerio de Salud, Presidencia de la Nación (2008) Guía de Práctica Clínica Nacional sobre prevención, diagnóstico y tratamiento de la Diabetes Mellitus Tipo 2 para el primer nivel de atención, Buenos Aires, p. 75.

66. Congreso de la Nación. (27 de diciembre de 2013). Ley $\mathrm{N}^{\circ}$ 26.914 - Salud Pública. Boletín oficial 27-12-2013.

67. Estrategia Nacional de Salud para el cumplimiento de los objetivos sanitarios de la década 2011-2020. Gobierno de Chile. Santiago de Chile.

68. Hidalgo Á, Oliva J, Rubio M, Zozaya N, Villoro R, García S (2015) Estudios de coste de la diabetes tipo 2: una revisión de la literatura. Agencia de Evaluación de la Tecnologías Sanitarias, Instituto de Salud Carlos III, Ministerio de Economía y Competitividad.

69. World Health Organization (2018) Global health expenditure database.

70. García Bermúdez G, Gragera Martínez Águeda Isabel, Hidalgo Gómez B, Paloma Arbiza A (2017) Descripción de la población diabetic en España a través de la encuesta Europea de Salud (EESE). Trabajo fin de gradoFacultad de Farmacia, Universidad Complutense, Madrid, España.

71. Crespo C, Brosa M, Soria-Juan A, Lopez-Alba A, López-Martínez N, et al. (2013) Costes directos de la diabetes mellitus y de sus complicaciones en España (Estudio SECCAID: Spain estimated cost Ciberdem- Cabimer in Diabetes). Av Diabetol 29: 182-189. 